\title{
Improving Learners' Design Thinking in Information Technology Course via “4+1” Iterative Model
}

\author{
Qi Su and Jinlei Xu
}

\begin{abstract}
Design thinking as a human-centered and problem-solving method can provide ways for ill-structured and complicated problems. It is also as an ability which can stimulate creative thinking and cultivate creative ability. Based on D.School five-step model, a new instructional framework of design thinking called " $4+1$ " iterative model was constructed. Four-week classroom study was carried out with the experimental and control group to explore the effect of the new model in Information Technology course in a middle school. The result showed there were obvious differences between the two groups on the awareness of creation and design, the ability of understanding and making, and the awareness of cooperation and sharing. From the result of the satisfaction of the classroom, the degree of the satisfaction of the experimental group was higher than those in the control group. There was also obvious difference between the two groups on the satisfaction of the classroom. It showed that it could be widely applied in the classroom and promote the innovation of the traditional instruction.
\end{abstract}

Index Terms - Design thinking, D.School five-step model, "4+1" iterative model, Information technology course.

\section{INTRODUCTION}

Recently countries have paid unprecedented attention to the cultivation of learners' creative ability, such as EFA Global Monitoring Report by UNESCO [1], the 21st century skills by the United States [2], the key competencies by OECD [3], the Melbourne declaration by Australia [4], and the 21st century competencies in Japan [5]. Design thinking is a kind of problem-solving thinking method based on solution, and especially facilitates in solving weak or unknown complex problems. As a methodology, design thinking can provide new ideas for the current teaching mode of Information Technology Course in middle school. At the same time, as a kind of ability, it is also in line with the current literacy training requirement of students. It should become an important content in Information Technology Course for students' literacy training.

\section{LITERATURE REVIEW}

\section{A. Design Thinking}

Design thinking is also known as human-centered design or user-centered design. In recent years, it has been widely concerned by scholars. Bazjanac (1974) believed that in the field of architecture, design thinking could be traced back to

Manuscript received March 15 2020; revised June 2, 2020. This work was supported by Priority Academic Program Development of Jiangsu Higher Education Institutions in China.

The authors are with Nanjing Normal University, Nanjing, 210097 China (corresponding author: Jinlei Xu; e-mail: $57057661 @$ qq.com). the construction design of Egyptian pyramids [6]. Herbert Alexander Simon asserted that "all successful managers are designers." [7] According to Rowe [8], design thinking is the way for designers to solve problems. The studies make design thinking popular in various fields. The latest definition of design thinking is proposed by Gruber et al. (2015) [9], design thinking is an creative people-oriented method, which puts the observation and discovery of the needs of people with only slight differences or even tacit understanding at the forefront of the creative process. Design thinking includes a series of iterative activities, 1) the exploration of data collection to identify user needs; 2) the definition of design standards and problems; 3 ) the aggregation of various design concepts, and 4) prototype production and testing. Therefore, the attention or research on design thinking is mainly reflected in the process of solving specific problems in practice or action.

\section{B. Design Thinking Model}

In 2009, George Kembel of Hasso Plattner Institute of Design at Stanford (D.School for short) proposed the design thinking process, which includes five steps such as "Empathy-Identify-Ideate-Build-Test" [10]. In 2010, D.School revised the classic five step model of design thinking, including five steps of "Empathize-Define-Ideate-Prototype-Test" [11], which attracted the attention and application of designers in various fields.

Based on the current research on the theory and application of design thinking, from the perspective of methodology, design thinking is considered as a set of methodology system to support design creation and problem-solving, which can effectively alleviate the problems of the instructional model in Information Technology Course. The characteristics of design thinking "based on creation" is an important support for enriching the instructional model. Nowadays, teachers are also designers, and teaching should be seen as a process of design [12]. Design thinking and design thinking model can be applied in a design, but the classic five step model of design thinking proposed by D.School is such a broad model that it can be applied to almost any kind of design process. It is this characteristic that determines its lack of pertinence for certain specific design processes. In order to improve the efficiency and effect of the model in some specific situations, it needs some modifications. Under this background, according to the characteristics of the Information Technology curriculum and the needs of teaching practice, a more practical teaching model needs to be established combined with the D.School design thinking model. Additionally, it is precisely because of the difference in the classroom teaching and non-teaching field situations that the subjectives and targets have also changed, so the design 
thinking model applied in classroom teaching should be different from the universal model.

According to the analysis of the essence of design thinking by Owen, professor of the IIT School of design in Chicago, the development and cultivation of design thinking should start from two major elements of process and content (see Fig. 1), covering the "analysis synthesis" and "symbol reality" construction of the thinking space [13].

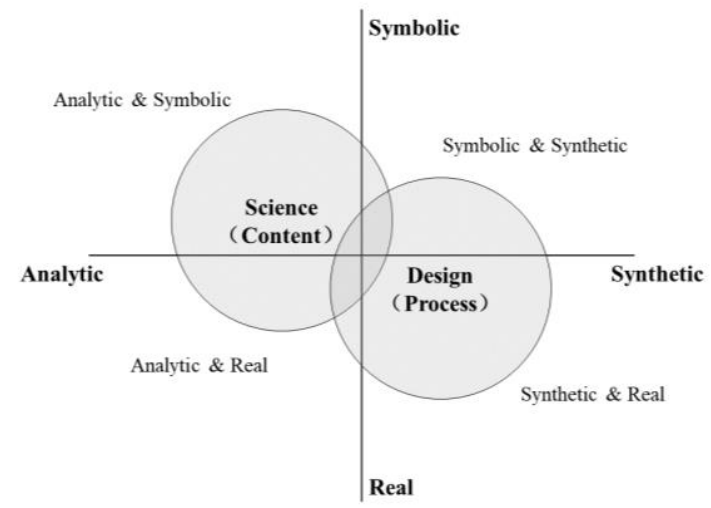

Fig. 1. Owen's design thinking model. Instructional design of " $4+1$ ” iterative model.

Based on the D.School model, a framework for instructional design of Information Technology Course was developed in a middle school. In addition, from the perspective of ability, design thinking is described as a kind of designer different from others complicated thinking ability. The ability of design thinking emphasizes "people-oriented". It can train students' ability of design thinking while innovating instructional design with the help of design thinking method. Through the combination of design thinking method and design thinking ability, the instructional design can realize "cultivating design thinking ability with design thinking method".

Combined with the classic five step model of D.School design thinking (see Fig. 2, left), it includes:1) Empathize, such as empathy thinking, which requires that the service object of the work to be the center, and try to stand at the user's point of view to see the problem and think about the solution as much as possible, which is the starting point of design thinking; 2) Define. After understanding the user's needs, the problem should be defined to the greatest extent, such as defining the problem to be solved, and clearly explaining the work content with concise language; 3) Ideate, which is to adopt the principle of "divergence first and concentration later", use brainstorming to propose as many solutions as possible, classify and focus these ideas through aggregate thinking, and finally select the best solution; 4) Prototype, which is to put the best solution into action in order to reflect on and improve the works. A prototype of works should be displayed in the most simplified way. The prototype stage pays attention to the output of results and finding problems or bottlenecks in the process of prototyping, so as to provide information for the optimization of subsequent works; 5) Test, which is advocated by design thinking, is to reexamine works by testing the prototype of works, to test the efficacy of works and find out the existing problems in time, and even to adjust and perfect early definition of problems made before.
Based on Owen's understanding of the design process, the process is mainly reflected in the "synthesis" between "reality and symbol". Combined with the teaching requirements of middle school Information Technology course and the subject teaching knowledge that teachers have in teaching practice, the classic five step model of D.School is applied to middle school Information Technology Course instruction, and the process framework of instructional design is constructed (see Fig. 2, right)
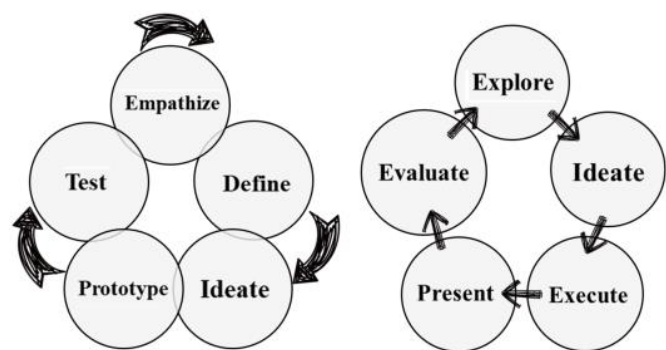

Fig. 2. Instructional design framework based on five-step design thinking $\operatorname{model} \wedge$.

After a round of teaching pre-experiment with the theme of "presentation design and production", combined with the feedback of teachers in the experimental school and the problems existing in the above process framework, the final instructional model, " $4+1$ " iteration model (as shown in Fig. 3 ), will be used to guide the instruction with the theme of "application document design and production".

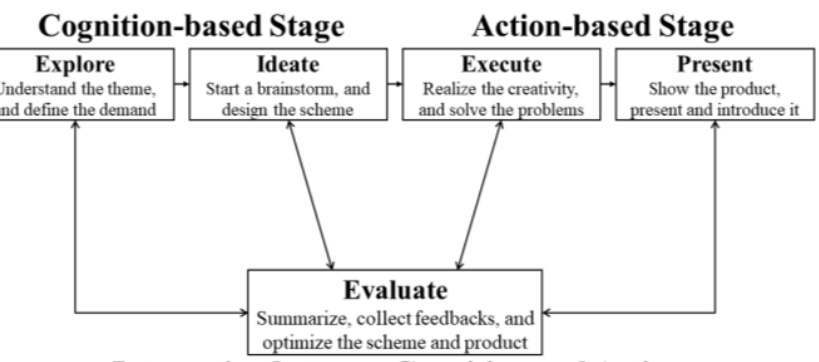

Interaction between Cognition and Action

Fig. 3. "4+1" iterative model.

1) Explore is corresponding to the Empathy and Define phase in the classic five-step model of D.School. In the D.School model, empathy mainly focuses on getting as many users' feelings and ideas as possible, and define emphasizes to determine the intentions of users and define the needs of the problems precisely through the results of empathy. Taking the existing teaching mode of Information Technology curriculum into consideration, the new model combines the empathy phase and define phase into Explore. Here empathy is regarded as a method to meet the needs of problem solving, and all tasks to prepare and lay the foundation for the design and production of classroom works belong to the explore stage. Generally, in this stage of classroom, the old knowledge will be reviewed, the new knowledge introduced, and the test taken.

2) Ideate is corresponding to the Ideate phase in the D.School model. There are two main tasks completed in this stage: one is to strengthen students' mastery and understanding of knowledge, including strengthening students' recollection of existing knowledge and promoting the understanding of new knowledge, ensuring the close 
connection between students' information technology knowledge and skills and actual operation, so that students' subsequent design direction is more clear; the other is to guide students to carry out the design of works and learn the team cooperation and brainstorming according to the defined project needs analysis. Brainstorming is the embodiment of visual thinking of design thinking which can help find the optimal solution in the continuous discussion and correction, Concept maps should be used in the design process. Paper, pen and other tools as many as possible are to visualize the thinking, not only to facilitate the students' modification of the design scheme, but also to make the teachers' supervision and evaluation of the progress, which is the embodiment of social thinking of design thinking.

3) Execute is corresponding to the Prototype phase in the D.School model. Most of the class hours of middle school Information Technology course are based on the production of works as the final orientation of the classroom. In the production stage, students are required to produce the final works according to the design scheme. In this stage, students' abilities of knowledge understanding and skill mastering are examined by ensuring the output of classroom results, which is the core part of Information Technology course.

4) Present is corresponding to the Test phase in the D.School model. Design thinking requires that the work must be able to be displayed and introduced to other people. After all products are designed and produced, they must be simulated and tested in real environment to ensure their applicability and practicability. At this stage, students will mainly rely on the form of independent or cooperative demonstration and explanation for the public display and introduction of works, and strive to gain recognition and understanding outside the team.

5) Evaluate. As a teaching link with various forms, evaluation mainly refers to the test or feedback behavior between teachers and students or within students in any process of the whole project task promotion, which is an important learning activity in the class. The evaluation process does not exist independently at the end of the learning process, but is divided into a variety of understandings, scattered at any time point in the above four stages, in order to quickly and timely optimize students' solutions. For example, when a teacher or other students evaluate a work in the presentation stage, the team should return to the exploration stage and the creation stage to reunderstand and define the work, and then make targeted modifications.

Most tasks in the Explore and Ideate stage occur in the students' cognition, which to some extent serves for the subsequent production and presentation, so they are collectively referred to as the "cognition-based stage". The Execute and Present stage is mainly the stage in which students show their ideas as concrete works and practical operations, so they are collectively referred to as the "action-based stage". Teaching and learning are also design processes, which follows the iterative nature of design, and the evaluation stage does not exist independently at the end of learning activities but runs through the whole learning process. Although the new model is similar to a "design-implement-evaluate" process, it is fundamentally different from the ADDIE model
(Analysis-Design-Develop-Implement-Evaluate) proposed in systematic instructional design. ADDIE is an instructional design development model that can help teachers carry out instructional design; It explains how to conduct an instructional design, which is the procedure for teachers to carry out instructional design. The new model is an instructional design model that can help teachers organize the teaching process; It explains how to teach, that is, the teacher's procedure for classroom teaching, or the procedure for students to learn. In addition, it is known that the PDCA (Plan-Do-Check-Act) mode is suitable for scientific procedures. Since the process of teaching is a typical scientific procedures, the "4+1" iterative model also follows the PDCA cycle model. That is to say, in a teaching stage, the learning process has no end, but a spiraling upward trend.

\section{Indicators of Students' Design Thinking Ability}

The design thinking content design, which focuses on the analysis process between reality and symbol, emphasizes the importance of analysis, and specifically analyzes the ability training dimension of design thinking. Most studies explore the theoretical or practical application from the perspective of process or methodology, but some researches regard it as a kind of ability to cultivate. For example, the research on the cultivation of design thinking ability in high school Information Technology course, through the construction of design thinking psychological operation process model, the key links of the cultivation of students' design thinking ability are divided into image accumulation training, thinking divergence training, association and imagination training and decision-making ability training. Zhu and $\mathrm{Li}$ (2015) proposed that design thinking is a kind of thinking form that visualizes and constructs the fuzzy attribute in the design process, which is manifested in the design ability possessed by the designer after learning the theory of design knowledge or the practice of design activities, both of which are basically the same in connotation.

On the basis of the above concepts and classifications, combined with the requirements of Information Technology teachers for students' ability, the training content of design thinking ability is divided into four parts: learning interest and attitude, creation and design consciousness, understanding and execution ability, cooperation and sharing consciousness (as shown in Fig. 4.), which is also the basis for the verification of design thinking teaching effect. Based on the " $4+1$ " iterative model, the four dimensions of students' design thinking ability in middle school Information Technology course are cultivated, and innovation is made from two aspects of method process and training content, realizing the linkage between form and content.

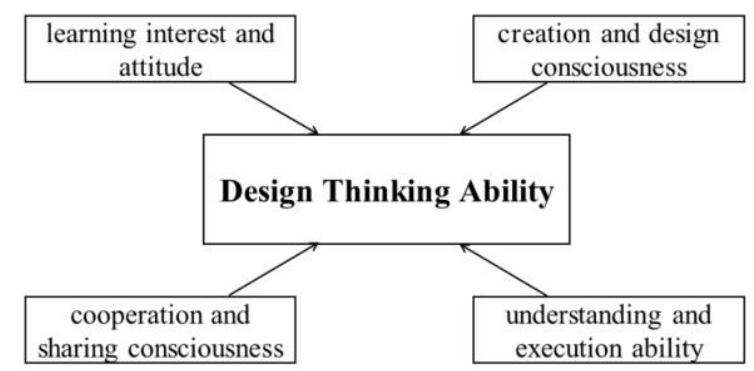

Fig. 4. Evaluation framework of design thinking ability. 


\section{Research Questions}

Based on the classic five step model of D.School design thinking, a new teaching model called " $4+1$ " iterative model was constructed. Taking WPS instruction in middle school Information Technology Course as an example, the study designed based on design thinking is carried out from two aspects of process and content. Thus, the following research questions were addressed in this study:

1) Does " $4+1$ " iterative model in the classroom of information technology course improve middle school students' abilities of design thinking?

2) Can students accept and be satisfied with " $4+1$ " iterative model applied in the classroom?

\section{METHOD}

\section{A. Participants}

The experiment was conducted in a middle school located in Xuanwu District in Nanjing, China. A total of 64 students in two classes from Grade 7 participated in this study. One class is the experiment group and the other is the control group. There are both 32 students in each group. The unit of "application document design and production" in Information Technology Course was selected as the learning content. All the participants have learned basic knowledge in primary school and have basic knowledge and operation skills of software. Thus, the learning content of this unit in middle school will pay more attention to relatively advanced application and evaluation. Combined with the learning objectives and experimental design, four class hours of teaching practice will be carried out in four weeks to complete the synchronous instruction of the experimental group and the control group. The experiment was carried out from February to April 2019.

\section{B. Procedure}

TABLE I: TEACHING SCHEDULE FOR THE EXPERIMENTAL GROUP

\begin{tabular}{|c|c|}
\hline Lesson Stage & Teaching Process \\
\hline $\begin{array}{l}\text { Lesson 1: } \\
\text { Explore \& } \\
\text { Ideate \& } \\
\text { Evaluate }\end{array}$ & $\begin{array}{l}\text { Carry out the transition of teaching content and guide } \\
\text { students to stimulate their thinking. First, the teaching } \\
\text { arrangement of this chapter is introduced. After that, } \\
\text { students will discuss the format design of individual and } \\
\text { group electronic brochures and draw the design } \\
\text { drawing. At the same time, pre-test survey will be } \\
\text { completed to understand the students' starting ability. }\end{array}$ \\
\hline $\begin{array}{l}\text { Lesson 2: } \\
\text { Ideate \& } \\
\text { Execute \& } \\
\text { Evaluate }\end{array}$ & $\begin{array}{l}\text { Guide the students to make electronic brochures } \\
\text { according to the design scheme, make a concentrated } \\
\text { comment on the first draft of the work and the design } \\
\text { drawing, and explain the treatment skills of existing and } \\
\text { possible problems. Each group is required to evaluate } \\
\text { the works of other groups, and each group should make } \\
\text { specific modifications according to the teachers' and } \\
\text { peers' comments. }\end{array}$ \\
\hline $\begin{array}{l}\text { Lesson 3: } \\
\text { Execute \& } \\
\text { Evaluate }\end{array}$ & $\begin{array}{l}\text { Further completion of the group work to improve and } \\
\text { beautify the work, and complete the group coursework } \\
\text { exhibition preparation. }\end{array}$ \\
\hline $\begin{array}{l}\text { Lesson 4: } \\
\text { Present \& } \\
\text { Evaluate }\end{array}$ & $\begin{array}{l}\text { Each group will conduct the demonstration and } \\
\text { explanation of the coursework and the classroom } \\
\text { evaluation. The revised final draft will be shared with } \\
\text { the class, and the post-test survey will be completed. }\end{array}$ \\
\hline
\end{tabular}

For the experimental group, the teaching arrangement of the four class hours is shown in Table I. For the control group, the teacher continues to follow traditional instructional model. The learning content is divided into four parts according to the textbook: mixed arrangement of graphics and text and basic element processing, document merging and layout adjustment, chart insertion and advanced element processing, independent decoration and page beautification. In addition, one part of knowledge points and key points of operation will be learned in each class hour, and four independent situation cases will be used in the four class hours. Based on the semi-finished works given at the beginning of each class hour, students are guided to understand the corresponding knowledge points and complete the class tasks according to the unified work requirements on the basis of the materials provided.

\section{Instrument}

According to the four dimensions of the training content of design thinking ability, 13 items of a questionnaire were constructed, including 4 items in the dimension of learning interest and attitude, 4 items in creation and design consciousness, 3 items in the ability of understanding and execution ability, 2 items in the sense of cooperation and sharing consciousness. In addition, in order to understand the students' satisfaction with the new instructional model, 3 items were constructed to investigate the satisfaction. Based on a Likert-type scale ranging from 1 (strongly disagree) to 5 (strongly agree), with the help of SPSS 22.0 software, the experimental data are analyzed and summarized.

\section{DATA ANALYSIS AND RESUlts}

\section{Reliability and Validity Test}

All the students in the two groups participated in the same pre-test and post-test. From the results of reliability analysis, the value of the questionnaire is 0.946 (see Table II), and the values of all dimensions are also above 0.790 , which shows that the questionnaire has high reliability and high reliability of the results.

TABLE II: RELIABILITY ANALYSIS RESULTS

\begin{tabular}{ccc}
\hline Variables & $\begin{array}{c}\text { Cronbach's } \\
\text { Alpha }\end{array}$ & $\begin{array}{c}\text { Cronbach's Alpha Based } \\
\text { on Standardized Items }\end{array}$ \\
\hline $\begin{array}{c}\text { learning interest and } \\
\text { attitude }\end{array}$ & .813 & .810 \\
\hline $\begin{array}{c}\text { creation and design } \\
\text { consciousness }\end{array}$ & .795 & .794 \\
\hline $\begin{array}{c}\text { understanding and } \\
\text { execution ability }\end{array}$ & .892 & .893 \\
\hline $\begin{array}{c}\text { cooperation and } \\
\text { sharing consciousness }\end{array}$ & .789 & .791 \\
\hline satisfaction & .862 & .865 \\
\hline Total & .946 & .946 \\
\hline
\end{tabular}

TABLE III: KMO AND BARTLETT's TEST RESULTS

\begin{tabular}{lll} 
Kaiser-Meyer-Olkin Measure of Sampling Adequacy & $\mathbf{. 8 7 2}$ \\
\hline Bartlett's Test of & Approx. Chi-Square & 794.133 \\
Sphericity & df & 120 \\
& Sig. & .000 \\
\hline
\end{tabular}

KMO and Bartlett tests were carried out to determine the validity of the questionnaire, and the KMO value was 0.872 
(see Table III), indicating that the relationship between variables of the questionnaire was strong.

\section{E. Analysis of Pre-test Survey Results}

From the results shown in Table IV, it can be seen that before the instructional experiment, there was no difference in the two groups in the four dimensions of the design thinking ability. In addition, there was no significant difference between the two groups in the recognition and satisfaction of the classroom (see Table IV).

TABLE IV: RESULTS OF INDEPENDENT SAMPLES TEST OF PRE-TEST

\begin{tabular}{|c|c|c|c|c|}
\hline & & Mean & $\mathbf{t}$ & Sig(2-tailed) \\
\hline \multirow{2}{*}{$\begin{array}{c}\text { learning } \\
\text { interest and } \\
\text { attitude }\end{array}$} & $\begin{array}{c}\text { experimental } \\
\text { class }\end{array}$ & 2.9297 & \multirow[t]{2}{*}{.121} & \multirow[t]{2}{*}{.904} \\
\hline & control class & 2.9531 & & \\
\hline \multirow{2}{*}{$\begin{array}{l}\text { innovation } \\
\text { and design } \\
\text { consciousne } \\
\text { ss }\end{array}$} & $\begin{array}{c}\text { experimental } \\
\text { class }\end{array}$ & 2.8359 & \multirow{2}{*}{-.787} & \multirow{2}{*}{.434} \\
\hline & control class & 2.6719 & & \\
\hline \multirow{2}{*}{$\begin{array}{l}\text { understandi } \\
\text { ng and } \\
\text { execution } \\
\text { ability }\end{array}$} & $\begin{array}{c}\text { experimental } \\
\text { class }\end{array}$ & 2.6663 & \multirow{2}{*}{.084} & \multirow{2}{*}{.933} \\
\hline & control class & 2.6881 & & \\
\hline \multirow{2}{*}{$\begin{array}{l}\text { cooperation } \\
\text { and sharing } \\
\text { consciousne } \\
\text { ss }\end{array}$} & $\begin{array}{c}\text { experimental } \\
\text { class }\end{array}$ & 2.7344 & \multirow{2}{*}{-1.590} & \multirow{2}{*}{.117} \\
\hline & control class & 2.3281 & & \\
\hline \multirow{2}{*}{$\begin{array}{c}\text { design } \\
\text { thinking } \\
\text { ability(total) }\end{array}$} & $\begin{array}{c}\text { experimental } \\
\text { class }\end{array}$ & 2.7916 & \multirow[t]{2}{*}{659} & \multirow[t]{2}{*}{.513} \\
\hline & control class & 2.6603 & & \\
\hline \multirow{2}{*}{$\begin{array}{l}\text { cooperation } \\
\text { and sharing } \\
\text { consciousne } \\
\text { ss }\end{array}$} & $\begin{array}{c}\text { experimental } \\
\text { class }\end{array}$ & 2.9378 & \multirow{2}{*}{-.312} & \multirow{2}{*}{.756} \\
\hline & control class & 2.8653 & & \\
\hline
\end{tabular}

\section{F. Analysis of Post-Test Survey Results}

TABLE V: RESULTS OF ANOVA OF POST-TEST (ANALYSIS OF VARIANCE)

\begin{tabular}{|c|c|c|c|c|}
\hline & & Mean Square & $\mathbf{F}$ & Sig. \\
\hline \multirow{3}{*}{$\begin{array}{c}\text { learning } \\
\text { interest and } \\
\text { attitude }\end{array}$} & Between Groups & 1.000 & \multirow{3}{*}{2.423} & \multirow{3}{*}{.125} \\
\hline & Within Groups & .413 & & \\
\hline & Total & & & \\
\hline \multirow{3}{*}{$\begin{array}{l}\text { creation and } \\
\text { design } \\
\text { consciousness }\end{array}$} & Between Groups & 2.954 & \multirow{3}{*}{4.586} & \multirow{3}{*}{$.036^{*}$} \\
\hline & Within Groups & .644 & & \\
\hline & Total & & & \\
\hline \multirow{3}{*}{$\begin{array}{l}\text { understanding } \\
\text { and execution } \\
\text { ability }\end{array}$} & Between Groups & 2.265 & \multirow{3}{*}{4.427} & \multirow{3}{*}{$.039 *$} \\
\hline & Within Groups & .512 & & \\
\hline & Total & & & \\
\hline \multirow{3}{*}{$\begin{array}{c}\text { cooperation } \\
\text { and sharing } \\
\text { consciousness }\end{array}$} & Between Groups & 3.285 & \multirow{3}{*}{4.306} & \multirow{3}{*}{$.042 *$} \\
\hline & Within Groups & .763 & & \\
\hline & Total & & & \\
\hline \multirow{3}{*}{ total } & Between Groups & 2.277 & \multirow{3}{*}{4.385} & \multirow{3}{*}{$.040^{*}$} \\
\hline & Within Groups & .519 & & \\
\hline & Total & & & \\
\hline \multirow{3}{*}{ satisfaction } & Between Groups & 2.372 & \multirow{3}{*}{4.640} & \multirow{3}{*}{$.035^{*}$} \\
\hline & Within Groups & .511 & & \\
\hline & Total & & & \\
\hline
\end{tabular}

Table V showed that after the instructional experiment, there was a significant difference in the three dimensions of "creation and design consciousness", "understanding and execution ability" and "cooperation and sharing consciousness" between the two groups. Totally, there was a significant difference in the design thinking ability between the two groups. It also showed that there was a significant difference between the two groups in satisfaction.

\section{DISCUSSION AND CONCLUSION}

\section{A. Improve the Ability of Design Thinking}

Under the guidance of design thinking model, the research put forward the process method and content dimension of instructional design. Based on the pre-test, teaching experiments were carried out in two groups with no significant difference in initial ability. Through data analysis, it could be concluded that the design thinking method had a significant effect on the cultivation of students and the improvement of classroom environment. Application of the new teaching model based on design thinking could improve students' comprehensive ability in three aspects: creation and design consciousness, understanding and execution ability, cooperation and sharing consciousness. Compared with the traditional teaching model, it was more dynamic and could fully improve students' abilities of creativity. However, there was no significant effect on the cultivation and improvement of learning interest and learning attitude.

\section{B. Satisfaction with the New Instructional Model}

The significant difference between the two groups in satisfaction showed that the application of " $4+1$ " iterative model in middle school Information Technology course could be accepted and recognized by students, which directly reflected the possibility of further promotion. It was proved that design thinking had the potential to become the guiding ideology of Information Technology instructional design model and the development direction of ability training, and would get more and more attention in the near future.

\section{Innovation of " $4+1$ " Iterative Model}

It is worth noting that the instructional design and implementation of Information Technology course, as a typical design process, also followed the iteration of general design. Once any error was found in the evaluation stage, it needed to go back to the initial stage of design immediately to correct and modify. Therefore, the process of instructional design was not linear, but iterative, and the found error also belonged to "effective failure". Thus, the improvement of design thinking to teachers and students was not only limited to its own efficacy, but also lay in the stimulation of effective failure so as to indirectly realize the secondary promotion. Teachers could also guide the occurrence of effective failure through the form of fault or doubt in the teaching process, so as to improve the efficiency of students' learning and the effect of classroom evaluation to a greater extent.

\section{Limitation and Future Study}

Due to there are many frameworks of design thinking method and the application differences among different subjects are obvious, the research of innovative teaching model based on design thinking still cannot be stopped. Each new model means to add improvement to the innovation of 
Information Technology course instructional model.

In the future, it will be a trend to integrate the concept and connotation of the three levels of design thinking. Although in recent years, design thinking is widely used in business management, product design, education and other scientific fields, but its own concept is not completely unified. Most scholars only choose one or two of the dimensions to conduct the research. Most of them belong to the application research. Little attention is paid to the re-development of the concept of design thinking itself. In the instructional studies of design thinking ability training based on design thinking method, a series of activity settings and learning arrangements exactly combine the two levels of the ability and the method of design thinking. Through the comprehensive consideration of empathy ability, finding multiple solutions, communication and cooperation, construction model, visual thinking, social thinking, etc., the instructional design is carried out to promote the innovation of instructional model of Information Technology course, it also provides new ideas for the research of multi-angle understanding the integration of design thinking.

\section{CONFLICT OF INTEREST}

The authors declare no conflict of interest.

\section{AUTHOR CONTRIBUTIONS}

Qi Su analyzed the data and wrote the original draft; Jinlei $\mathrm{Xu}$ reviewed and edited the final paper; all authors had approved the final version.

\section{ACKNOWLEDGMENT}

This research was supported by the Priority Academic Program Development of Jiangsu Higher Education Institutions in China.

\section{APPENDIX}

Items of the Design Thinking Ability and Model Satisfaction Test

1) I like to learn how to design and make application documents.

2) I was active, attentive and focused while learning.

3) I think it's very important for me to master the knowledge and skills related to the application documents.

4) I have a high enthusiasm and interest in learning how to design and making e-tabloids, e-magazines and reports.

5) There are some original ideas in my e-tabloid magazine.

6) After finishing the e-tabloid magazine, I can explain why its content and form should be designed in the current style.

7) While making application documents, my teammates can help each other and give suggestions to others.

8) The teacher's teaching method has greatly improved my understanding of designing and making application documents.
9) I have fully understood the concept and procedure of designing and making application documents.

10) I attach great importance to drawing blueprint and have formed the habit of designing first and then making.

11) After 4 weeks of study, it is easy for me to design and make an application document.

12) In the past few weeks of study, I often share my thoughts and ideas to others.

13) I can produce a complete and creative work according to my early design.

14) The instructional design is scientific and suitable for me to learn how to design and make application documents.

15) When the teacher explains the examples, the classroom atmosphere is very active and the participation is very high.

16) I have mastered the basic skills and have the ability to finish my work on time.

\section{REFERENCES}

[1] The EFA Global Monitoring Report Team, "EFA global monitoring report 2016: Education for people and planet: Creating sustainable futures for all," UNESCO, 2016.

[2] B. Trilling and C. Fadel, 21st Century Skills: Learning for Life in Our Times, John Wiley \& Sons, 2009.

[3] Organisation for Economic Co-operation and Development, The Definition and Selection of Key Competencies: Executive Summary, OECD, 2005.

[4] A. Barr, J. Gillard, V. Firth et al., Melbourne Declaration on Educational Goals for Young Australians, Ministerial Council on Education, Employment, Training and Youth Affairs, 2008.

[5] D. Kimura and M. Tatsuno, Advancing 21st Century Competencies in Japan, Asia Society: Center for Global Education, 2017.

[6] V. Bazjanac, "Architectural design theory: Models of the design process," Basic Questions of Design Theory, vol. 3, p. 20, 1974.

[7] H. A. Simon, The Sciences of the Artificial, 3rd ed. Cambridge, MA MIT Press, 1996.

[8] P. G. Rowe, Design Thinking, Cambridge, MA: The MIT Press, 1991.

[9] M. Gruber, N. De Leon, G. George, and P. Thompson, "Managing by design," Academy of Management Journal, vol. 58, pp. 1-7, 2015.

[10] G. Kembel, Awakening Creativity, Chautauqua Institution, 2009.

[11] H. Plattner, An Introduction to Design Thinking Process Guide, The Institute of Design at Stanford: Stanford, 2010.

[12] D. Henriksen and C. Richardson, "Teachers are designers: Addressing problems of practice in education," Phi Delta Kappan, vol. 99, no. 2 pp. 60-64, 2017.

[13] C. Owen, "Design thinking: Notes on its nature and use," Design Research Quarterly, vol. 2, pp. 16-27, 2006.

[14] Z. Zhu and F. Li, "Information technology course design faced to discipline thinking," E-education Research, vol. 36, pp. 83-88, 2015.

Copyright (C) 2020 by the authors. This is an open access article distributed under the Creative Commons Attribution License which permits unrestricted use, distribution, and reproduction in any medium, provided the original work is properly cited ( $\underline{\text { C B B 4.0) }}$.

Qi Su was born in Xinji, China, on Aug. 11, 1996. He is a graduate student of School of Education Science, Nanjing Normal University, Nanjing, China. He was an undergraduate student at Nanjing Normal University from 2015 to 2019 and earned his bachelor degree in 2019. Now he is a graduate student at Nanjing Normal University.

Jinlei Xu was born in Danyang, China on June 3, 1981. He received the $\mathrm{Ph}$ $\mathrm{D}$ from Nanjing Normal University. He is now an associate professor in Nanjing Normal University, Nanjing, China. 